\title{
PRACTICAL JUDGMENTS
}

\section{Essays in Culture, Politics, and Interpretation}

What does it mean to be both a professor of philosophy and a public intellectual in an age when every CEO is hailed as an intellectual, every adman a visionary? When the opinions of TV pundits and 'fast thinkers' seem to carry the day? When academics bemoan the loss of critical engagement and dialogue?

The essays and book reviews collected in Practical Judgments represent philosopher and cultural theorist Mark Kingwell's negotiation of the space where academe collides with the world outside the ivory tower. Kingwell considers cricket and consciousness, dandies and television, the ethics of books and lifestyles, and the possibility of critical theory. He looks to Nietzsche, Husserl, and Adorno for inspiration, but also to Cary Grant, Bruce Mau, and Jorge Luis Borges.

Throughout, Kingwell shows a deep respect for the philosophical enterprise in its peculiar current conditions and a commitment to thinking clearly and with self-awareness about these conditions. Intended as both a philosophical examination of the commonplace virtues of wonder, civility, and common sense, Practical Judgments calls attention to the process of thinking and, by example, encourages the reader to engage in similar philosophizing. The book itself is structured to show the arc of thought, from the more abstract, scholarly examinations of people and ideas, to critical reflections on the impetus 
for philosophy and its possibilities as a force for change in the world around us.

Practical Judgments reveals the sources and developments of Kingwell's thought and examines the nature and limits of intellectual engagement. It displays Kingwell's political commitment to a hermeneutic form of social democracy by revealing a careful attention to the texture of daily cultural affairs. Arguing for a form of critical engagement without which political action is impossible, Kingwell shows that attention to everyday life is worthwhile both in itself and as part of a larger philosophical endeavour.

mark KIngwell is Professor in the Department of Philosophy and Senior Fellow of Massey College, University of Toronto. He is the author of five previous books, including Marginalia (1999) and The World We Want (2000), and has been awarded many prizes for his writings as well as an honorary doctorate from the Nova Scotia College of Art and Design. His work has appeared in publications such as the New York Times Magazine, Saturday Night, Adbusters, Maclean's, Utne Reader, the Globe and Mail, and Harper's Magazine, where he is a contributing editor. He also has a regular column in the National Post. 


\section{PRACTICAL JUDGMENTS}

\section{ESSAYS IN CULTURE, POLITICS, AND INTERPRETATION}

Mark Kingwell

UNIVERSITY OF TORONTO PRESS

Toronto Buffalo London 


\section{www.utppublishing.com}

(C) University of Toronto Press Incorporated 2002

Toronto Buffalo London

Printed in Canada

Reprinted in paperback 2004

ISBN 0-8020-3675-9 (cloth)

ISBN 0-8020-3801-8 (paper)

(6)

Printed on acid-free paper

National Library of Canada Cataloguing in Publication

Kingwell, Mark Gerald

Practical judgments : essays in culture, politics and interpretation / Mark Kingwell.

Includes bibliographical references and index.

ISBN 0-8020-3675-9 (bound). - ISBN 0-8020-3801-8 (pbk.)

I. Title.

AC8.K55 $2002 \quad 081 \quad$ C2002-901514-6

The University of Toronto Press acknowledges the financial assistance to its publishing program of the Canada Council for the Arts and the Ontario Arts Council.

University of Toronto Press acknowledges the financial support for its publishing activities of the Government of Canada through the Book Publishing Industry Development Program (BPIDP). 
For Brennan,

outside the door 
This page intentionally left blank 